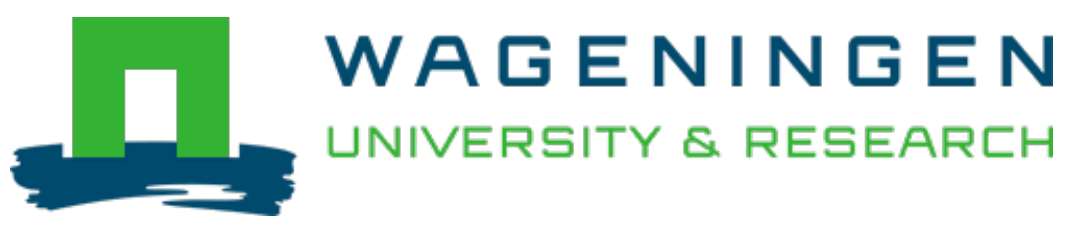

\title{
Ebb and flood nutrient delivery system for sustainable automated crop production
}

Acta Horticulturae

Giacomelli, G.A.; Weel, P.A.; Blok, C.

https://doi.org/10.17660/ActaHortic.2020.1296.143

This article is made publicly available in the institutional repository of Wageningen University and Research, under the terms of article $25 \mathrm{fa}$ of the Dutch Copyright Act, also known as the Amendment Taverne. This has been done with explicit consent by the author.

Article 25 fa states that the author of a short scientific work funded either wholly or partially by Dutch public funds is entitled to make that work publicly available for no consideration following a reasonable period of time after the work was first published, provided that clear reference is made to the source of the first publication of the work.

This publication is distributed under The Association of Universities in the Netherlands (VSNU) 'Article $25 \mathrm{fa}$

implementation' project. In this project research outputs of researchers employed by Dutch Universities that comply with the legal requirements of Article $25 \mathrm{fa}$ of the Dutch Copyright Act are distributed online and free of cost or other barriers in institutional repositories. Research outputs are distributed six months after their first online publication in the original published version and with proper attribution to the source of the original publication.

You are permitted to download and use the publication for personal purposes. All rights remain with the author(s) and / or copyright owner(s) of this work. Any use of the publication or parts of it other than authorised under article $25 \mathrm{fa}$ of the Dutch Copyright act is prohibited. Wageningen University \& Research and the author(s) of this publication shall not be held responsible or liable for any damages resulting from your (re)use of this publication.

For questions regarding the public availability of this article please contact openscience.library@,wur.nl 


\title{
Ebb and flood nutrient delivery system for sustainable automated crop production
}

\author{
G.A. Giacomelli1,a, P.A. van Weel² and C. Blok ${ }^{3}$
}

${ }^{1}$ University of Arizona, CEAC, Biosystems Engineering, Tucson, Arizona, USA; ${ }^{2}$ Weel.Invent, Sassenheim, The Netherlands; ${ }^{3}$ Wageningen University \& Research, Greenhouse Horticulture, Bleiswijk, The Netherlands.

\begin{abstract}
For more than 40 years ebb and flood irrigation and nutrient delivery systems have been nurturing crops within greenhouse controlled environments. Bedding plants, potted plants, cut flowers and even tomatoes have been produced. An overview and critical discussion of the delivery of water, dissolved oxygen and plant nutrients to the root zone of the crop using the ebb and flood principles is discussed in this article. Ebb and flood systems have functioned within automated crop production systems from table transport devices to concrete floor heating systems. The benefits were the easily manageable means to uniformly provide water, dissolved oxygen and plant nutrients to the root zone of the crop, without requiring a fixed plumbing connection, either for inflow during flood or for drainage at ebb. The results were effective transport of water, nutrients and oxygen from the bottom of the root zone upwards, and with saturation of the bottom of the root zone, allowing minimal flushing of nutrients and other dissolved substances from the root zone. All unused irrigation water was collected and returned to storage for future use, creating a recirculating hydroponic system which conserved water and nutrients and directly benefited the environment by eliminating discharge. Fundamental design criteria and operation management practices; integration with concrete floor heating system; and, examples of successful applications are discussed, as are limitations and future applications.
\end{abstract}

Keywords: hydroponics, controlled environment, greenhouse, grow room, plant factory, crop production, growing media, substrate, soilless cultivation

\section{INTRODUCTION}

The development of the ebb and flood nutrient delivery system (E\&F) began in 1981 as a potential solution to concerns about irrigation efficiency, crop transport and handling and hygiene in overhead irrigated container plant production. E\&F became a fundamental component of an integrated plant production system with a concrete floor growing surface (Buwalda et al., 1994, 1995). The integrated system provided several specific advantages, including: eliminating manual watering, flexibility in design of internal transport of potted plants, heating the root zone with low temperature water, and reducing bacterial and fungal diseases because of cultivation surfaces that were easy to clean and disinfect between cultivation cycles (Benton-Jones, 2007). Once implemented several serendipitous attributes were realized, including: heating energy savings (if used in conjunction with a heated floor), creation of dedicated growing media, increased water use efficiency, elimination of nutrient rich water discharged into the environment, and most importantly, an improved crop quality with root zone warming (Gent and Ma, 1998).

In the 1980s, rising heating fuel prices prompted the demand for energy saving and led to the concept of using reject or waste heat such as $35^{\circ} \mathrm{C}$ cooling water of electrical generating power stations to heat the greenhouse with a concrete-capped floor heat storage system (Mears and Manning, 1996; Manning and Mears, 1981). Alternatively, plastic 18-mm diameter tubes placed within a $10-\mathrm{cm}$ layer of concrete floor warmed by waste heat or with a traditional boiler were able to maintain desired greenhouse air temperatures, if used in conjunction with

aE-mail: giacomel@ag.arizona.edu 
an energy screen at night (van de Braak, 1989).

At that time capillary mats, placed under pots or flats and located on the top surface of the elevated bench, were commonly used to distribute irrigation water. Capillary mats for bottom watering of potted plants had become a source of fungal and bacterial diseases within 1-2 years of initial use (Dole et al., 1994). Cleaning by steam sterilization or with yearly replacement was required to resolve the growth of algae and moss on the mat surface. Salt build-up and compaction of the mat material limited the useful life of the mat. These were reducing the optimal water, oxygen and nutrient supply to the plants, and often resulted in root diseases.

However, with capillary mats used on a heated concrete floor, the heating energy from the floor would be lost in evaporation of water from the mats. A dry surface of the floor was therefore required for efficient floor heating, as well as for sanitation and plant growth control. The E\&F water delivery system became the solution for heated floor systems.

In 1979 the first heated concrete floor system was combined with an overhead watering system ('t Hart and van Weel, 1988). The distribution of water to the pots was not uniform, since the foliage of the plants caused a large variation in the amount of water received for each, since there was no redistribution of water by a capillary mat. The E\&F system was able to improve the water distribution to the pots, but also to reduce plant diseases and leaf damage caused by wet foliage. By 1989, there were 140 ha of concrete floors in Dutch greenhouses producing vegetable seedlings, potted plants and cut flowers in pots using the E\&F water and nutrient delivery system. (Ploeger, 1992).

Labour costs traditionally restricted the manual watering to about once a week, but the heated floor not only increased the evaporation from the growing medium, but also the transpiration by the plant, requiring more frequent watering. The excessive water holding capacity of traditional growing media was previously required because of infrequent watering cycles. As a result, the new E\&F water system was initially unable to maintain plant quality. However, research proved that daily watering provided more growth and improved plant quality, and it maintained plant nutrition. However, with a daily watering frequency these former growing media were causing root diseases from a lack of oxygen supply in the lower region of the root zone (Vogelezang, 1993). A standardized mix of $80 \%$ peat with $20 \%$ perlite in combination with special container pots designed with feet that raised the pot $8 \mathrm{~mm}$, or more above the surface resolved these irrigation-related problems, allowing frequent watering to keep water and nutrients at stabile and desired levels within the growing media.

With the initial prevalence of root disease, the potential risks of spreading the disease organisms by the continued re-use of the recirculating water of the system were studied. Introduction of Fusarium oxysporum f. sp. cyclaminis, either into the nutrient solution or into the growing media, did not spread disease in a cyclamen crop using the newly designed container and the new growing medium when produced on tables of an E\&F system (Rattink, 1990). Growing media samples from the containers adjacent to the infected container were not found positive for disease. The presumption was that the irrigation water movement into the containers was predominantly carrying spores upwards into the individual inoculated container and only very few disease spores were transported downwards and into the recirculating irrigation water, because the capacity of the spores to actively swim downwards against a vertical upward flow was known to be limited to a few millimeters (Lugtenberg, 2015). The volume of drainage leaving the containers is limited to the small difference between the water volume in a container at the ending of the flood period and prior to the beginning of the ebb period, and the water volume in a container after all water on the floor or table has been drained away.

Within seven days after the initial infection, soil and root particles were found settled to the bottom of the nutrient solution storage tank which created the environment for fungal spores to grow (van Os et al., 1999; Rattink, 1990). Methods have been developed for regular removal of the organic materials as they return from the floor and prior to entering the storage tank, including mechanical screening and the slow sand filtration procedure (van Os et al., 1998, 1999). Also, the intake of the pump was not placed at the very bottom of the tank, instead at a higher location, allowing debris to remain at the bottom (Figure 1). 


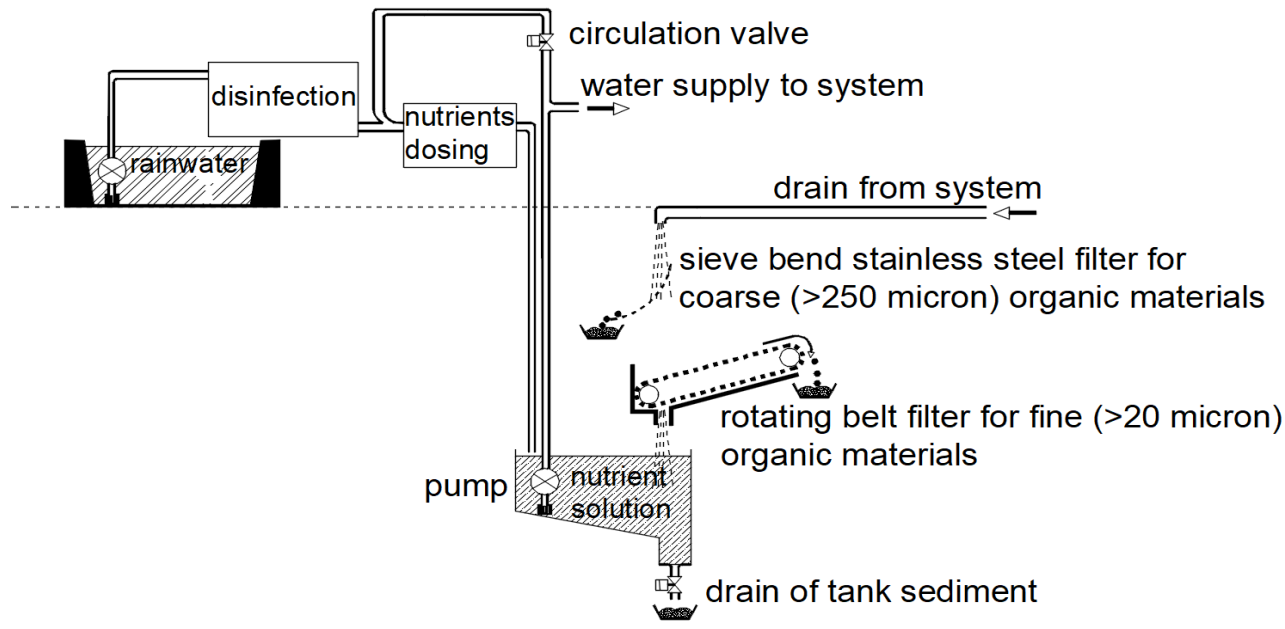

Figure 1. Ebb and flood water and nutrient management system for bench or floor.

Controlled environments utilizing recirculating hydroponic crop production systems such as E\&F have been successfully applied to commercial greenhouse crops for potted plants (Ploeger, 1992), bedding plants, cut flowers (Warmenhoven and Baas, 1995; van Weel et al., 1992), and transplants and rooted cutting production (Buwalda et al., 1995). Tomato crop production within a highly automated and labor efficient, single-truss tomato production system was developed and evaluated by Giacomelli et al. (1994). In this system tomato plants were treated like potted plants, grown at high density (11 plants $\left.\mathrm{m}^{-2}\right)$ within a continuous year-round cropping strategy to provide for efficient, predictable tomato fruit production (Fischer et al., 1990). Similar recirculating nutrient water systems are currently being developed for vegetable crop production, such as leafy greens and lettuce, for indoor solesource electrically lighted plant production facilities (Kozai, 2019).

\section{MATERIALS AND METHODS}

\section{Ebb and flood nutrient delivery system}

Ebb and flood irrigation (E\&F), also known as ebb and flow, flood and drain, or subirrigation, is defined as an irrigation system delivering water to the bottom of the root zone of a plant that is located on an impermeable or contained surface by creating a body of water, which after sufficient time is absorbed into the root zone, and that part which is not absorbed is returned to storage, allowing the surface in between containers to dry quickly. The cycle repeats to maintain a controllable range of water status in the root zone.

The E\&F water distribution system consists of a 1) nutrient solution storage tank located below grade, 2) pump and pipe network to deliver the water from the tank to the concrete floor or to the bench surfaces, 3 ) gravity flow pipe network to return unused water to the storage tank, 4) controller to activate the pump and control valves to deliver to the desired locations, 5) automated fresh water refill, 6) water particle filter, 7) microbial control, and if used, (8) fertigation technology to provide desired plant nutrient formulation.

Ebb and flow nutrient delivery systems can be designed for operation with concrete floor systems or with raised bench systems. Crops successfully grown on the floor (Figure 2), include vegetable transplants, bedding plants, and green or flowering potted plants. Hardware for the supporting frameworks of benches is unnecessary for production on the concrete floor. However, a means to handle and transport the flats or potted crops must be included in the design to ensure efficient labor and space utilization (Giacomelli et al., 1991). 


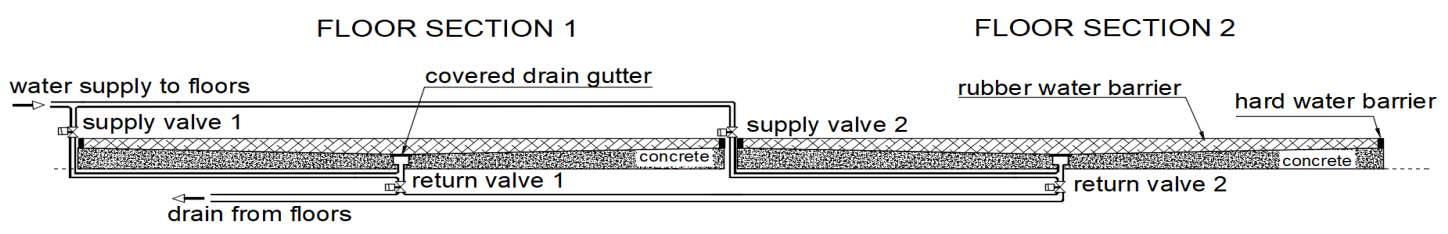

Figure 2. Ebb and flood system for concrete floors in the greenhouse. Components include water barrier, providing containment, supply and return plumbing and valves.

\section{Concrete floor systems.}

The concrete floor section (Figure 2) is prepared at grade with a $1 \%$ highly uniform slope profile to the midpoint of each greenhouse bay, where a drain gutter collecting water along the length of the bay directs the water, when the return valve is activated, to the nutrient water storage tank located below grade. A screen located at the drain gutter prevents large particles from returning to storage. The supply water is pumped from the water and nutrient management storage tank (Figure 1) to each bay, filling to a depth of 3-4 cm within less than $5 \mathrm{~min}$ and draining to a damp surface within 10 additional min. Total watering cycle per bay is $15 \mathrm{~min}$. The concrete surface is made water impermeable by using a levelling/screeding machine during pouring and then by covering the freshly poured concrete with plastic to prevent evaporation during the hardening process. The floor sections are separated by aluminum strips between each bay. The concrete surface is free of all materials, allowing for unrestricted and maximum use of floor area for crop spacing and access for transport vehicles. A porous surface is used in an outdoor version of the E\&F floor (Figure 3).

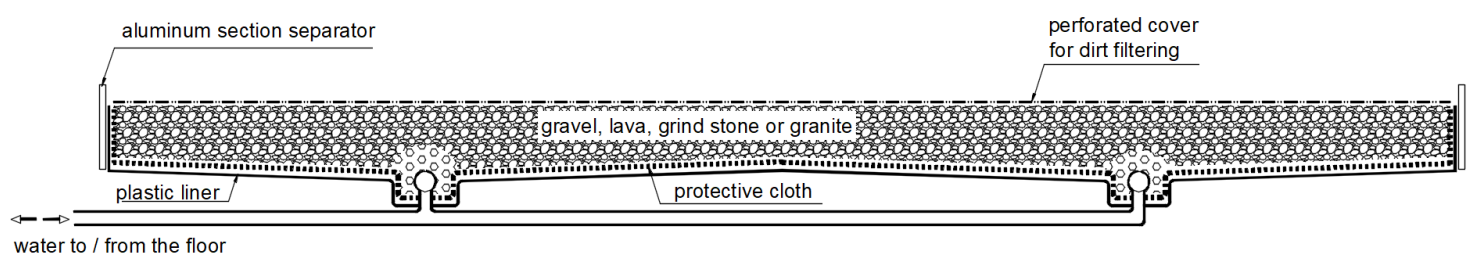

Figure 3. Ebb and flow system for outdoor production on porous bed. Components include water impermeable liner, providing containment, supply and return plumbing within same pipe, and particulate non-concrete surface.

\section{Bench systems.}

Fixed or transportable benches (Figure 4) with dimensions adjusted to the bay width (e.g., $1.6 \times 6 \mathrm{~m}$ ) are mounted above the floor allowing for easier hand labor access, or automation solutions for plant maintenance tasks and transport and handling. They are covered with an impermeable rigid plastic profile which directs all water to the lowest point at one end of the bench where a siphon device (unpowered) drains nutrient water from the bench surface to a gutter below to return the water to the nutrient storage tank. The supply water is pumped from the water and nutrient management storage tank (Figure 1) to each bench or group of benches, filling to a depth of 1-2 cm within $5 \mathrm{~min}$ and draining within 10 min for a total water cycle per bay of $15 \mathrm{~min}$. A large particle screen is located at the siphon drain (Figure 5). The E\&F plumbing is not attached to the benches which is advantageous when incorporated into an automated transport and handling system. Crops produced on benches using E\&F include flowering plants (e.g., Phalaenopsis, Begonia, Bromeliacea) and green plants or herbs in small pots, as well as seedlings.

Components of the E\&F water and nutrient management system (Figure 1) include fresh water filter and disinfection, nutrient dosing device, storage tank with pump, sensors and controls to distribute irrigation water and nutrients to benches or floors. Mechanical 
filtering devices are required to remove particulates from the drainage water returning from the bench or floor.

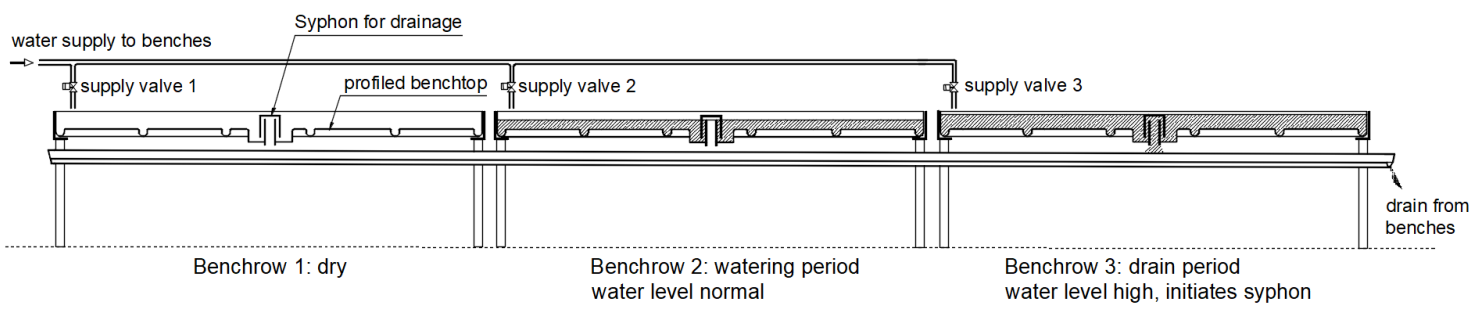

Figure 4. Ebb and flow system for fixed or transportable benches in the greenhouse. Components include water impermeable bench surface, providing containment, and supply and return plumbing and valves which are not attached to the benches.

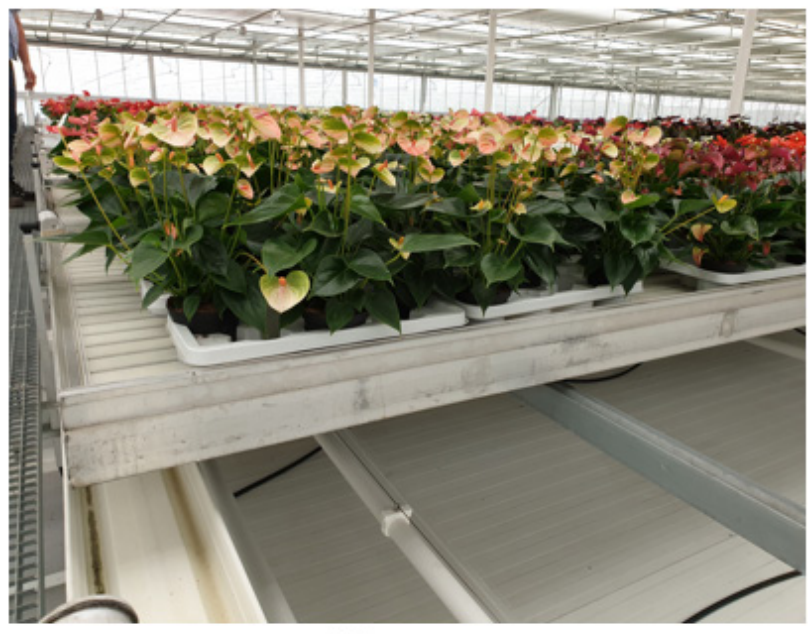

(a)

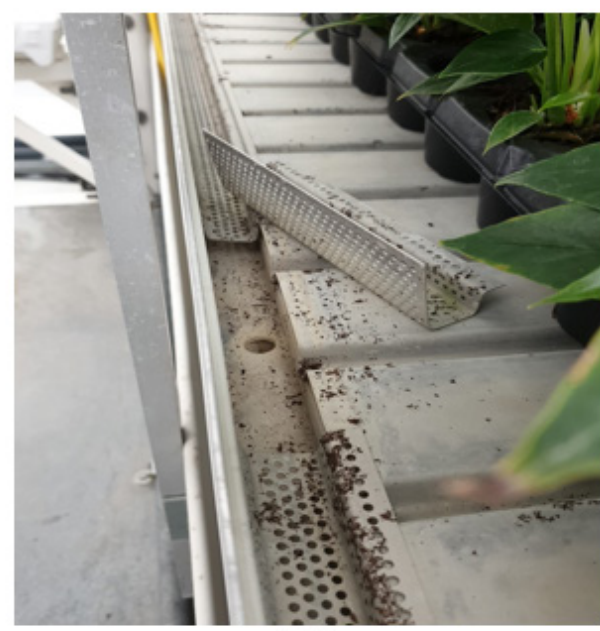

(b)

Figure 5. (a) Transportable bench with pots; (b) Bench profile, screen and drain.

\section{Growing media}

There are two distinct criteria required for a growing medium to be effective within an $\mathrm{E} \& \mathrm{~F}$ irrigation system which provides irrigation water to saturate the base of the root zone during the flooding. The first is to provide a minimum air content for root respiration. The irrigation water saturates the bottom 1-2 $\mathrm{cm}$ of a container filled with a growing medium, and that must allow for the proper supply of oxygen to the roots after draining (Blok and Gérard, 2013; Blossfeld et al., 2009; Dresbøll and Thorup-Kristensen, 2012). For sufficient air supply rates, a minimum of $20 \%-\mathrm{v} / \mathrm{v}$ of air-filled pore space in the growing medium is required. However, in practise $15 \%-\mathrm{v} / \mathrm{v}$ has proven acceptable. Highly water absorbing and/or fine materials like peat and coir pith can easily be over-irrigated. Therefore, materials with a much lower saturation percentage, or rather a higher air content at saturation, such as perlite and wood fiber, should be mixed in E\&F growing media, and typically in quantities between 15 and $40 \%-\mathrm{v} / \mathrm{v}$.

A second criterion requires that the growing medium re-saturate quickly (i.e., transport the irrigation water) to the top of the container within the duration of the irrigation cycle. Therefore, a typical requirement for growing media used in E\&F is a minimum air content of $15 \%$ at saturation and a minimum water uptake rate of $50 \%-\mathrm{v} / \mathrm{v}$ within $15 \mathrm{~min}$ when starting at air dry material and a water table just touching the growing medium (Blok et al., 2008). Perlite and/or coir pith are added $(20 \%-\mathrm{v} / \mathrm{v}$ or more) to peat or other media to improve the resaturation rate. The minimum air content and minimum water uptake rate are criteria 
requiring contradictory physical properties for the growing medium, and therefore require the user to find an optimum combination for a given situation, for example peat/perlite; peat/coir; or, wood fiber. Table 1 includes physical properties of individual materials and mixtures for growing media.

Table 1. Examples of single constituents and typical E\&F container media mixtures and their values for dry bulk density (DBD, $\left.\mathrm{kg} \mathrm{m}^{-3}\right)$, saturation (\%-v/v), container capacity (CC, \%-v/v, at $-2.5 \mathrm{~cm}$ suction), and water uptake rate (WUR, \%v/v, within $15 \mathrm{~min}$ ).

\begin{tabular}{|c|c|c|c|c|c|}
\hline Growing medium & $\begin{array}{c}\text { Mix } \\
(\%-v / v) \\
\end{array}$ & $\begin{array}{c}\mathrm{DBD}^{\mathrm{a}} \\
\left(\mathrm{kg} \mathrm{m}^{-3}\right)\end{array}$ & $\begin{array}{c}\begin{array}{c}\text { Saturation } \\
\text { (\%-v/v) }\end{array} \\
\end{array}$ & $\begin{array}{c}C^{C a} \\
(\%-v / v)\end{array}$ & $\begin{array}{c}\text { WUR }^{\mathrm{b}} \\
(\%-\mathrm{s} / \mathrm{v} \text { in } 15 \mathrm{~min})\end{array}$ \\
\hline Peat (milled white) & & 100 & 85 & 83 & 30 \\
\hline Coir pith & & 120 & 78 & 72 & 70 \\
\hline Coir pith/fiber & $85 / 15$ & 100 & 68 & 60 & 50 \\
\hline Perlite $<6 \mathrm{~mm}$ & & 100 & 55 & 55 & 50 \\
\hline Perlite $<4 \mathrm{~mm}$ & & 80 & 65 & 63 & 55 \\
\hline Wood fiber & & 60 & 50 & 40 & 20 \\
\hline Peat/perlite & $80 / 20$ & 110 & 75 & 70 & 50 \\
\hline Peat/coir pith/perlite & $50 / 30 / 20$ & 115 & 75 & 72 & 55 \\
\hline
\end{tabular}

aaccording to CEN 13041 (2011); baccording to Blok et al. (2008).

\section{Operational experiences}

Successful crop production with E\&F depends on the type of crop and the age of the crop in production, as well as the volume of growing medium, the formulation of the growing medium, and the greenhouse environmental conditions. However, there are several general rules for proper design and operation for irrigation (and fertigation) with E\&F systems. These include: hydrate at a growing medium moisture content which allows for quick re-saturation. The lower threshold for irrigation is $30-40 \%-\mathrm{v} / \mathrm{v}$ depending on the growing medium constituents and pot size. The values in Table 1 for the water uptake rate (WUR) are, by definition, the amount of water absorbed per volume of dry growing medium. In practise the growing medium is not allowed to reach that dryness level and re-saturation is faster.

The minimum growing medium moisture content used as a set point for an irrigation event is often decided by the grower, based on experience and manual lifting of the pot. It is becoming more common to use the solar radiation sum and control system with sensors measuring container weight or electronically measured moisture content and EC (Choi et al., 2014; Miralles-Crespo and van Iersel, 2011). Electronic sensors for watering event control are more consistent and the resulting growing medium moisture content is beneficial for growth (Blok et al., 2017). The maximum flood depth $(<2 \mathrm{~cm}$ depth of root zone) and the time duration of the maximum flood depth $(<5 \mathrm{~min})$, translates into about $10 \mathrm{~min}$ of contact between irrigation solution and growing medium. The goal is to avoid air content of the growing medium of below $15 \%-\mathrm{v} / \mathrm{v}$ which translates into moisture contents of about $70 \%$ $\mathrm{v} / \mathrm{v}$ as maximum. Limitations of pumping capacity requires at least 5 min to complete a flood of 1-2 cm deep onto the floor or benchtop and into the containers and it is usually kept at maximum level for 3-5 min. The draining requires another $5 \mathrm{~min}$. Prolonged submersion of the plant roots increases the risk of oxygen deprivation for the lower roots. Generally, the cycle duration is limited to less than $15 \mathrm{~min}$. The actual duration depends on the tables or floors volumetric capacity and the maximum volumetric flow capacity of the pump.

The electronic measurement of EC provides an estimate of the total nutrient salts available to the plant (Mak, 2001). The electronic monitoring of EC will also measure unwanted (e.g., $\mathrm{Na}, \mathrm{Cl}$ ), and surpluses of elements (e.g., Ca, $\mathrm{SO}_{4}$ ) (Warmenhoven and Baas, 1995). Water and soil samples should be regularly evaluated at a laboratory for content.

A combination of the water content and a nutrient measurement provides effective insight into water and nutrient uptake of the container plants. This is especially relevant as the plants depend on being supplied with exactly the proper ratio between water and nutrient 
supply. This is unlike other cultivation systems in which routinely an oversupply of about $30 \%$ water and 50\% nutrients is given (resulting in drainage). In E\&F the EC of the solution supplied must match the uptake EC of the plant much more closely than in other fertigation systems. Since the inception of E\&F systems, developments in plant breeding and cultivation systems have increased the production of plant mass per unit area, and consequently the plant nutrient uptake and irrigation EC of most plants have increased $20-50 \%$.

\section{CONCLUSIONS}

The nutrient delivery system based on E\&F irrigation has successfully produced quality plants within the greenhouse whether on concrete floor or on transportable table, offering crop uniformity, as well as water, nutrient and energy savings, and reduced disease, algae and labor tasks. As part of a nutrient and water recirculating system, the E\&F provided reduced environmental impacts. In addition, when combined with a table transport system to improve labor efficiency, or with a concrete floor heating system to improve energy efficiency and crop production quality, the E\&F system provided beneficial advantages over previous growing systems.

The physical properties of growing media in E\&F systems must be modified to meet the needs of moisture content and air content. Within a recirculating irrigation system, electronic monitoring of water content and nutrient content will, in combination with frequency, duration and depth of nutrient water delivery, further improve the quality and production rate of greenhouse crops.

\section{ACKNOWLEDGEMENTS}

The authors want to thank all those growers who entrusted the success of their crops with an E\&F nutrient delivery system, and for the water and nutrients that they recovered.

\section{Literature cited}

Benton-Jones, J. (2007). Les techniques de la culture hydroponique. Maximum Yield 7 (2), 18-24.

Blok, C., and Gérard, S. (2013). Root oxygen use determination of propagated cucumber on rockwool cubes. Acta Hortic. 1013, 73-79 https://doi.org/10.17660/ActaHortic.2013.1013.5.

Blok, C., De Kreij, C., Baas, R., and Wever, G. (2008). Analytical methods used in soilless cultivation. In Soilless Culture. Theory and Practise, M. Raviv, and H. Lieth, eds. (Amsterdam, The Netherlands: Elsevier).

Blok, C., Jackson, B.E., Guo, X., de Visser, P.H.B., and Marcelis, L.F.M. (2017). Maximum plant uptakes for water, nutrients, and oxygen are not always met by irrigation rate and distribution in water-based cultivation systems. Front Plant Sci 8, 562 https://doi.org/10.3389/fpls.2017.00562. PubMed

Blossfeld, S., Gansert, D., and Wade, B. (2009). Planar optodes: promising tools for non-invasive 2D imaging of rhizospheric dynamics of $\mathrm{pH}, \mathrm{O}_{2}$ and $\mathrm{CO}_{2}$. Paper presented at: Int. Plant Nutrition Colloquium XVI.

Buwalda, F., Baas, R., and van Weel, P.A. (1994). A soilless ebb-and-flow system for all-year-round chrysanthemum. Acta Hortic. 361, 123-132 https://doi.org/10.17660/ActaHortic.1994.361.10.

Buwalda, F., Frenck, R., Löbker, B., van den Berg-De Vos, B., and Kim, K.S. (1995). Ebb and flow cultivation of chrysanthemum cuttings in different growing media. Acta Hortic. 401, 193-200 https://doi.org/10.17660/ ActaHortic.1995.401.23.

CEN 13041. (2011). Soil improvers and growing media - determination of physical properties - dry bulk density, air volume, water volume, shrinkage value and total pore space.

Choi, E.Y., Seo, S.K., Choi, K.Y., and Lee, Y.B. (2014). Development of a non-drainage hydroponic system with a coconut coir substrate by a frequency domain reflectometry sensor for tomato cultivation. J. Plant Nutr. 37 (5), 748-764 https://doi.org/10.1080/01904167.2013.868479.

Dole, J.M., Cole, J.C., and Vonbroembsen, S.L. (1994). Growth of poinsettias, nutrient leaching, and water-use efficiency respond to irrigation methods. Hortic. Sci. 29 (8), 858-864 https://doi.org/10.21273/HORTSCI. 29.8.858.

Dresbøll, D.B., and Thorup-Kristensen, K. (2012). Spatial variation in root system activity of tomato (Solanum lycopersicum L.) in response to short and long-term waterlogging as determined by $15 \mathrm{~N}$ uptake. Plant Soil 357 (12), 161-172 https://doi.org/10.1007/s11104-012-1135-5.

Fischer, D.R., Giacomelli, G.A., and Janes, H.W. (1990). A system of intensive tomato production using ebb-flood 
benches. Professional Horticulture 4 (3), 99-106.

Gent, M.P.N., and Ma, Y.Z. (1998). Root zone heating and greenhouse tomato. Hortic. Sci. (Prague) 33 (1), 47-51.

Giacomelli, G.A., Fang, W., Ting, K.C., and van Weel, P.A. (1991). Defining internal transport systems in greenhouses. Acta Hortic. 295, 233-242 https://doi.org/10.17660/ActaHortic.1991.295.29.

Giacomelli, G.A., Ting, K.C., and Mears, D.R. (1994). Design of a single truss tomato production system (STTPS). Acta Hortic. 361, 77-84 https://doi.org/10.17660/ActaHortic.1994.361.6.

Hart, C., and van Weel, P.A. (1988). Constructional aspects of some heated concrete floors for greenhouses. J. Agric. Eng. Res. 39 (3), 161-172 https://doi.org/10.1016/0021-8634(88)90093-5.

Kozai, T. (2019). Smart Plant Factory: the Next Generation Indoor Vertical Farms (Springer Nature Singapore Pte Ltd.).

Lugtenberg, B. (2015). Principles of Plant-Microbe Interactions: Microbes for Sustainable Agriculture (Cham: Springer International Publishing).

Mak, A.T.Y.Y.D.M. (2001). Nitrogen nutrition of Spathiphyllum 'Sensation' grown in peat and coir-based media with two irrigation methods. Hortic. Sci. (Prague) 36 (4), 645-649.

Manning, T.O., and Mears, D.R. (1981). Computer aided design of a greenhouse waste heat utilization system. Energ. Agric. 1, 5-20 https://doi.org/10.1016/0167-5826(81)90003-6.

Mears, D.R., and Manning, T.O. (1996). Redesign of a greenhouse waste heat system. Paper presented at: NABEC96 (Canaan Valley, West Virginia, USA).

Miralles-Crespo, J., and van Iersel, M.W. (2011). A calibrated time domain transmissometry soil moisture sensor can be used for precise automated irrigation of container-grown plants. Hortic. Sci. (Prague) 46, 889-894.

Ploeger, C. (1992). De structuur van de kamerplantenteelt in Nederland (Landbouw Economisch Instituut (LEIDLO)), 4.130.

Rattink, H. (1990). Epidemiology of Fusarium wilt in cyclamen in an ebb and flow system. Neth. J. Plant Pathol. 96 (3), 171-177 https://doi.org/10.1007/BF01974254.

van de Braak, N.J. (1989). New methods of greenhouse heating. Acta Hortic. 245, 149-157 https://doi.org/10. 17660/ActaHortic.1989.245.18.

van Os, E.A., van Kuik, F., Runia, W.T., and van Buuren, J. (1998). Prospects of slow sand filtration to eliminate pathogens from recirculating nutrient solutions. Acta Hortic. 458, 377-384 https://doi.org/10.17660/ActaHortic. 1998.458.49.

van Os, E.A., Amsing, J., van Kuik, F., and Willers, H. (1999). Slow sand filtration: a potential method for the elimination of pathogens and nematodes in recirculating nutrient solutions from glasshouse-grown crops. Acta Hortic. 481, 519-526 https://doi.org/10.17660/ActaHortic.1999.481.61.

van Weel, P.A., de Dood, J., and Woittiez, R.D. (1992). Cut-rose production in closed systems with emphasis on environmental aspects. Acta Hortic. 303, 15-22 https://doi.org/10.17660/ActaHortic.1992.303.2.

Vogelezang, J.V.M. (1993). Bench heating for potplant cultivation: analysis of effects of root- and air temperature on growth, development and production. Dissertation (Agricultural University).

Warmenhoven, M.G., and Baas, R. (1995). Chrysanthemum cultivation in a soilless ebb/flow system interaction of $\mathrm{NaCl}$, mineral nutrition and irrigation frequency. Acta Hortic. 401, 393-400 https://doi.org/10.17660/ ActaHortic.1995.401.48. 